\title{
Youth Perceptions of Early Marriage in SMA X Years 2021
}

\author{
${ }^{1}$ Eva Rahmawati, ${ }^{2}$ Jovita Melvira, ${ }^{3}$ Latifah Khumairah, ${ }^{4}$ Marsya Balkhies Alfaatihah \\ Faculty of Public Health, Muhammadiyah University of Jakarta \\ K.H. Ahmad Dahlan St, Cireundeu, Ciputat, South Jakarta, 15419 \\ E-mail: evarahmawati950@gmail.com
}

\begin{abstract}
Marriage is an inner and outer bond between a man and a woman as husband and wife to form a happy and eternal family (household) based on God Almighty. In the Law of the Republic of Indonesia, Number 1 of 1974 Article concerning Marriage, marriage itself has conditions, including that it must be approved by both prospective brides, and prospective brides who have not reached the age of 21 years must obtain permission from both parents. 1 Chapter II Article 7 Paragraph 1 of 1974 has explained that marriage is only permitted if the man reaches the age of 19 years and the woman has reached the age of 16 years. The type of research used is qualitative research with a qualitative descriptive study research design. The informants in this study were teenagers at SMA X South Tangerang. The informants who will be interviewed are 4 informants who are in high school. The results of this study indicate that there are undesirable events such as pregnancy out of wedlock because children have relationships that violate norms, forcing them to have early marriages, to clarify the status of the child they are carrying Economic difficulties are one of the factors causing early marriage, families who experience economic difficulties will tend to marry off their children at a young age to have early marriages. The impact of early marriage for women who are less educated and not ready to carry out their role as mothers will be less able to educate their children so that children will grow up poorly, which will be detrimental to the children's future. Then, under certain conditions, children who marry early tend not to pay attention to their education, especially when they get married immediately they get offspring, they will be busy taking care of their children and their families, so this can prevent them from continuing their studies to a higher level.
\end{abstract}

Keywords: Early marriage, Perception, Student 


\section{INTRODUCTION}

Marriage is an inner and outer bond between a man and a woman as husband and wife to form a happy and eternal family (household) based on God Almighty. In the Law of the Republic of Indonesia, Number 1 of 1974 Article concerning Marriage, marriage itself has conditions, including that it must be approved by both prospective brides, and prospective brides who have not reached the age of 21 years must obtain permission from both parents. Marriage law No.1 Chapter II Article 7 Paragraph 1 of 1974 has explained that marriage is only permitted if the man reaches the age of 19 years and the woman has reached the age of 16 years. The age of first marriage is permitted if the man reaches the age of 25 years and the woman reaches the age of 20 years. This provision is explicitly explained that every marriage performed by a prospective groom who is not yet 19 years old or a woman aged 16 years is referred to as an underage marriage.

Women aged 20-24 years who married before the age of 18 in 2018 are estimated to reach around 1,220,900 and this figure places Indonesia in the 10 countries with the highest absolute number of child marriages in the world. Then, BPS recorded $3.22 \%$ of women married under the age of 15 in 2020. Then, $27.35 \%$ of women married at the age of 16-18 years.

Adolescence is a period of human development. This period is a period of change or transition from childhood to adulthood which includes biological changes, psychological changes, and psychosocial changes. In most societies and cultures, adolescence generally begins at the age of 10-13 years and ends at the age of 18-22 years.

In general, adolescence is a behavior that always wants to try, including in terms of sexuality, especially early adolescence (10-12 years) which is the initial stage or the beginning of physical maturation.

\section{METHODS}

The type of research used is qualitative research with a qualitative descriptive study research design, namely seeking information by collecting data in the form of descriptions of works carried out by researchers through in-depth interviews using interview guidelines that aim to describe Adolescent Perceptions of Early Marriage in SMA X years 2021.

Sources of information or informants in this study were teenagers at SMA X South Tangerang. For the selection of informants by selecting a sample that is assessed according to the objectives or problems in the study. The informants who will be interviewed are 4 informants who are in high school. 


\section{RESULTS AND DISCUSSION}

Table 1. Results of Interview Data Analysis

\begin{tabular}{|c|c|c|c|c|c|c|}
\hline $\begin{array}{c}\text { Topic } \\
\text { (question) }\end{array}$ & $\begin{array}{c}\text { Meaning unit } \\
\text { (informant's answer) }\end{array}$ & Code & & Sub-category & Category & Theme \\
\hline $\begin{array}{l}\text { 1. What is } \\
\text { marriage? }\end{array}$ & $\begin{array}{l}\text { - } 2 \text { people who are } \\
\text { ready to unite to } \\
\text { build a family } \\
\text { - Marriage is an } \\
\text { obligation in religion } \\
\text { and is a form of } \\
\text { worship carried out } \\
\text { by a man and a } \\
\text { woman } \\
\text { - Marriage is a bond } \\
\text { between a man and a } \\
\text { woman who has the } \\
\text { legal status of the } \\
\text { country, in and } \\
\text { marriage is worship } \\
\text { which if carried out } \\
\text { will get a reward. } \\
\text { - Marriage is in the } \\
\text { religion of worship, } \\
\text { but in my opinion, } \\
\text { marriage is like a } \\
\text { process of } \\
\text { compromising } \\
\text { between our egos } \\
\text { and other people's } \\
\text { egos }\end{array}$ & $\begin{array}{l}\text { - Ready } \\
\text { build } \\
\text { household } \\
\text { - A worship } \\
\text { - Unite the ego }\end{array}$ & $\begin{array}{l}\text { to } \\
\mathrm{a}\end{array}$ & $\begin{array}{l}\text { Marriage } \\
\text { knowledge }\end{array}$ & Knowledge & $\begin{array}{l}\text { Early-age } \\
\text { marriage }\end{array}$ \\
\hline
\end{tabular}

In this section, the author conveys a set of structured information that provides conclusions and taking action. Contains exposure to data presented with topics by research statements and data analysis which are findings presented in the form of interviews.

Cognitive aspects are knowledge, understanding, application, and analysis. Cognitive aspects are related to perception, memory, learning, thinking, and problem-solving. It can be understood that in the process of human life it is always related to what is thought, felt, and done. From the results of research on knowledge of early marriage, the informant answered that it was a form of marriage based on family demands, unwanted events, or economic limitations. lack of knowledge of early marriage or marriage itself can cause problems in the family because they do 
not know their rights and obligations as husband and wife. This is because their physical or mental immaturity tends to have high selfishness.

On the other hand, there are undesirable events such as pregnancy out of wedlock, because children engage in relationships that violate norms, forcing them to have early marriages, to clarify the status of the child being conceived. Economic difficulties are one of the factors causing early marriage, families who experience economic difficulties will tend to marry off their children at a young age to have early marriages.

The affective aspect relates to feelings and includes emotional feelings related to feelings of pleasure or displeasure with early marriage. Women who are less educated and not ready to carry out their role as mothers will be less able to educate their children so that children will grow up poorly, which will be detrimental to their future. The existence of early marriage can interfere with the interest of students who still want to continue their education to a higher level and the emotions possessed by teenagers are not yet ready to marry which will later result in divorce and domestic violence and will also lead to risky pregnancies that occur by young women.

The conative aspect includes the tendency to act and behave towards early marriage. Under certain conditions, children who marry early tend not to pay attention to their education, especially when they get married immediately to get offspring, they will be busy taking care of their children and their families, so this can prevent them from continuing their studies to a higher level.

Getting married at an early age is based on the desire to marry at an early age based on the experience of parents and follow the example of families who marry at an early age, and can also be based on encouragement from parents and peers to marry at an early age.

\section{CONCLUSION AND SUGGESTIONS}

Cognitive Aspect is knowledge, understanding, application, and analysis Cognitive aspects related to perception, memory, learning, thinking, and problem-solving It can be understood that in the process of human life it is always related to what is thought (cognitive), felt (emotional) and what is done (interpersonal relationships).

The affective aspect is the aspect that concerns the emotions of the individual. Individuals in perceiving something can be through effective aspects based on the individual's emotions, this can arise because of the moral and ethical education obtained since childhood, this ethical and moral education. which ultimately becomes the basis of the individual is looking at something that is happening around him. Components are related to the tendency to act on the attitude object. 
Volume I Tahun 2021

November 2021
E-ISSN: 2808-5361 http://e-journal.fkmumj.ac.id/
Proceeding The First Muhammadiyah InternasionalPublic Health and Medicine

Conference

The conative aspect, this component shows the intensity of the attitude, which shows the size of the tendency of a person's reaction or response to an object.

It is better for teenagers before continuing the marriage ladder, they should understand or understand how the rights and obligations of husband and wife are by the Qur'an and the Sunnah of the Prophet Muhammad, to be able to foster a sakinah, mawwadah, and warahmah family, therefore education is very important to support the future. in front of a teenager

Better equip their teenagers with knowledge about religion, and be able to make mature decisions without rushing about marriage issues so that it doesn't affect the labor force on their teenagers because marriage is to get Allah's blessing and carry out the sunnah of the Prophet Muhammad.

\section{REFERENCES}

Agustriana, F., Angriani, P. and Hastuti, K. P. (2015) 'Persepsi pelajar sekolah menengah atas (SMA) terhadap pernikahan usia dini di kecamatan banjarmasin selatan kota banjarmasin', Jurnal Pendidikan Geografi, 2(4), pp. 38-49.

ALVRENIA, V. A. (2017) PENGARUH PENDIDIKAN KESEHATAN TERHADAP PERSEPSI PERNIKAHAN DINI PADA SISWA MADRASAH ALIYAH NEGERI 3 MALANG, KEC. DONOMULYO, KAB. MALANG, Repository UMM. UMM. Available at: http://dx.doi.org/10.1016/j.encep.2012.03.001.

Arianti, W. D. (2018) 'Persepsi Remaja tentang Pernikahan Dini di SMA Pesantren Guppi Samata Kecamatan Somba Opu Kabupaten Gowa'. Available at: http://eprints.undip.ac.id/52698/1/skripsi_proposal.pdf.

Badan Pusat Statistik (2020) 'Pencegahan Perkawinan Anak Percepatan yang Tidak Bisa Ditunda', Badan Pusat Statistik, pp. 6-10.

Databoks (2020) Jutaan Anak Perempuan Indonesia Lakukan Pernikahan Dini.

Femilanda, E. putri (2017) 'Gambaran pernikahan dini remaja putri di kecamatan kangkung kabupaten $\quad$ kendal', $\quad$ p. $1-51 . \quad$ Available at: http://eprints.undip.ac.id/52698/1/skripsi_proposal.pdf.

Ma'ruf, A. (2016) UPAYA PEMERINTAH DALAM MENCEGAH SEKS BEBAS PADA REMAJA DI KELURAHAN TIPULU KECAMATAN KENDARI BARAT KOTA KENDARI, Repository Perpustakaan IAIN KENDARI. IAIN KENDARI.

Pitriani, R. (2019) Persepsi Remaja Terhadap Pernikahan Dini di SMPN 1 Tarogong Kaler, Repository Unpad. 
Volume I Tahun 2021

November 2021
E-ISSN: 2808-5361 http://e-journal.fkmumj.ac.id/
Proceeding The First Muhammadiyah InternasionalPublic Health and Medicine

Conference

Salaemaeng, I. (2021) ANALISIS TERHADAP FENOMENA PENERAPAN PERKAWINAN DI BAWAH UMUR DI MAJELIS AGAMA ISLAM WILAYAH PATANI THAILAND SELATAN. UNIVERSITAS ISLAM NEGERI SULTHAN THAHA SAIFUDDIN.

Savendra, A. D. (2019) PENGARUH PERNIKAHAN DI BAWAH UMUR TERHADAP KEHARMONISAN RUMAH TANGGA (Studi Kasus Di Desa Banarjoyo Kecamatan Batanghari Kabupaten Lampung Timur). INSTITUT AGAMA ISLAM NEGERI (IAIN) METRO.

Setiawati, E. R. (2017) 'Pengaruh Pernikahan Dini Terhadap Keharmonisan Pasangan Suami dan Istri di Desa Bagan Bhakti Kecamatan Balai Jaya Kabupaten Rokan Hilir', Jom FISIP Volume 4 No. 1 Februari 2017, 4(1), pp. 1-13.

Setiawati, S. (2017) 'PERSEPSI REMAJA TERHADAP PERNIKAHAN DINI DI SMAN 1 BANGUNTAPAN KABUPATEN BANTUL YOGYAKARTA NASKAH'.

Sujanto, A. (2017) Persepsi Peserta Didik dalam Mengenakan Jilbab, UIN Lampung.

Umami, I. (2019) Psikologi remaja.

Yanti, Hamidah and Wiwita (2018) 'Analisis Faktor Penyebab Dan Dampak Pernikahan Dini Di Kecamatan Kandis Kabupaten Siak’, Jurnal Ibu dan Anak, 6(November), pp. 96-103. 